\title{
INVESTIGATION OF TRENDS IN METEOROLOGICAL DROUGHTS IN NIGĞDE PROVINCE
}

\author{
Onur ARSLAN * \\ Department of Civil Engineering, Faculty of Engineering, Niğde Ömer Halisdemir University, Niğde, Turkey
}

\begin{abstract}
Investigation of trends in meteorological droughts is important in water resources management. Niğde province is located in Konya Closed Basin and it is one of the most drought provinces receives low rainfall in Turkey. This study has two stages. In the first stage, Standardized Precipitation Index (SPI) values of Niğde province were calculated for 1-, 3-, 6-, 9-, 12-, 24- and 36-month time scales to identify meteorological droughts. In the second stage, trends in meteorological droughts in Niğde province were investigated by using Mann Kendall Rank Correlation (MKRC) test. Monthly total precipitation values for Niğde meteorological station between 1950 and 2015 were used for application. According to SPI values, 110 drought periods lasting for six months and more were determined for Niğde province for different time scales. The trend analysis results show that there have been statistically significant increasing trends at the $95 \%$ confidence level for all time scales except a 1-month time scale. This means that SPI values have shown a tendency towards wetness in Niğde province.
\end{abstract}

Keywords: Drought analysis, Trend analysis, Standardized Precipitation Index (SPI), Mann Kendall Rank Correlation (MKRC) Test, Niğde

\section{INTRODUCTION}

Drought is an important phenomenon causing economic, environmental and social impacts. According to a ranking based on severity, duration, loss and impacts, drought ranks first among thirty one natural hazards [1]. Drought begins as meteorological drought and later, meteorological drought can cause agricultural and hydrological droughts. When a meteorological drought happens, water managers can need to make changes in water resources management. Therefore, investigation of trends in meteorological droughts is important in water resources management.

Studies about trend analysis of meteorological droughts have been increasing in recent years. Chen et al., used Mann-Whitney-Pettitt (MWP) method to investigate historical trends of meteorological droughts in Taiwan. SPI values were calculated for a 3-month time scale. They determined increasing or decreasing trends in drought characteristics changing according to regions [2]. Blain applied trend analysis to the monthly values of the SPI in the state of São Paulo in Brazil. However, a statically significant trend was not found [3]. Ganguli and Reddy used Mann Kendall trend test to perform a trend analysis for 6-month SPI values for Western India. They stated that there was an upward trend for total study period [4]. Zhang et al., applied linear regression, Mann-Kendall, and Spearman's Rho tests to analyze trends in the SPI values of Aksu River Basin in Northwest China. SPI values were calculated for a 12-month time scale. They determined increasing trends for all stations and they observed significant trends at Aheqi, Baicheng, Keping and Kuche stations [5]. Achugbu and Anugwo performed a drought trend analysis using a non-parametric Mann-Kendall trend test for Kano. Droughts were analyzed by means of SPI for 3-, 6-, 9-, 12- and 24-month time scales. A statistically meaningful trend was not observed for the entire study period (1911-2010) [6]. Ionita et al., investigated the trends of droughts in Romania by using Spearman's Rho test. SPI values were estimated for 3-, 6- and 12-month time scales. They detected that the spatial distribution of drought trends in Romania was heterogeneous [7]. Osuch et al., analyzed the trends in projections of SPI in a 
future climate in Poland for 1-, 3-, 6-, 12- and 24-month time scales by using Mann Kendall test with Sen's slope estimator. They stated that the spatial pattern of the trend changed related to the climate model, the time scale and the bias correction [8]. Zarei and Eslamian employed linear regression, Mann Kendall and Spearman's Rho tests to analyze trends in the SPI values of arid regions of southern Iran. No significant trend was found in the SPI 12 series at the 5\% level [9].

Şen et al., stated that drought events over Turkey will be more frequent in the future [10]. In this study, SPI values of Niğde province were calculated for 1-, 3-, 6-, 9-, 12-, 24- and 36-month time scales to identify meteorological droughts. Then, a trend analysis in meteorological droughts in Niğde province was performed by using Mann Kendall Rank Correlation (MKRC) test.

\section{MATERIAL AND METHOD}

\subsection{Study Area and Material}

Niğde province is one of the most drought cities in Turkey receiving low rainfall. As can be seen from Figure 1, Niğde province is located in central Anatolia and it has a desertification risk above medium level. It is situated at an elevation of about $1300 \mathrm{~m}$ above sea level and the climate characteristics of the province present the continental climate (cold and snowy winters, hot and dry summers).

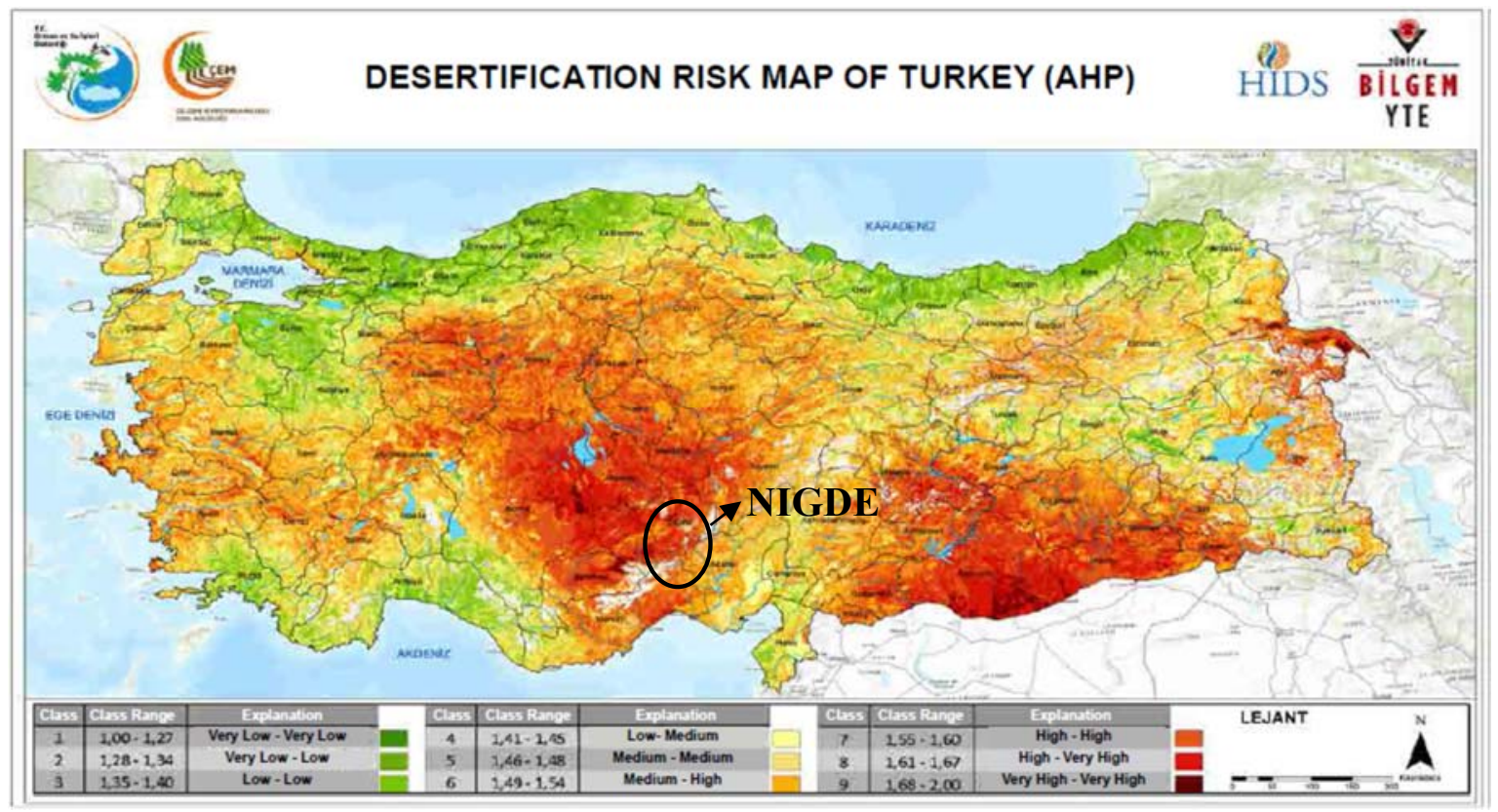

Figure 1. Study area and desertification risk map of Turkey [11]

In the study, monthly total precipitation values for Niğde meteorological station between 1950 and 2015 were obtained from Turkish State Meteorological Service. Niğde meteorological station is located between $34^{\circ} 42^{\prime \prime}$ east longitude and $35^{\circ} 59^{\prime \prime}$ North latitude [12]. Mckee was stated that at least 30 years data are required to accurately calculate SPI [13]. Therefore, data sets consisting of 66 years were used in this study.

\subsection{Standardized Precipitation Index (SPI)}

The Standardized Precipitation Index (SPI) developed by Mckee was used to identify meteorological droughts in Niğde Province. Index values can be calculated for different time scales $(1,3,6,9,12,24,48$ months, etc.) However, precipitation may not adapt normal distribution in 12 months or shorter periods. 
Therefore, each of the data sets is fitted to the Gamma distribution function [13]. In this study, SPI_SL_6 program was used for calculating SPI values. In this method, negative values indicate droughts.

Drought magnitude can be calculated by using the following equation:

$$
M=-\sum_{k=1}^{D} S P I_{k}
$$

Where, $\mathrm{M}$ is the drought magnitude, $\mathrm{D}$ is the drought duration in months and $\mathrm{k}$ is the time scale of SPI.

\subsection{Mann Kendall Rank Correlation (MKRC)}

The non-parametric Mann Kendall Correlation (MKRC) test was used to detect trends in SPI values for Niğde province. In this method, the direct curve-u(t) and the backward curve-u'(t) are used to identify the beginning of a trend. The value of $u(t)$ is calculated by using the following equations [14]:

$$
\begin{gathered}
t=\sum_{i=1}^{n} n_{i} \\
E(t)=i(i-1) / 4 \\
\operatorname{Var}(t)=i(i-1)(2 i+5) / 72 \\
u(t)=\frac{(t-E(t))}{\sqrt{\operatorname{Var}(t)}}
\end{gathered}
$$

Where, $t$ the test statistic, $n_{i}$ is the number of cases $x_{i}>x_{k}(i=1, \ldots ., n$ and $k=1, \ldots \ldots, i-1), E(t)$ is the mean of test statistic, $\operatorname{Var}(\mathrm{t})$ is the variance of test statistic, $\mathrm{u}(\mathrm{t})$ is the same as the $\mathrm{z}$ value, and $\mathrm{n}$ is the number of total data. Similarly, the values of $u^{\prime}(t)$ are computed backward, starting from the end of the series.

The significance of a trend is controlled by comparing $\mathrm{u}(\mathrm{t})$ values with $\mathrm{z}$ values at a selected confidence level. In this study, 95\% confidence level is selected for evaluation and so, $\mathrm{z}$ values are between +1.96 and -1.96 . Positive values of $\mathrm{u}(\mathrm{t})$ indicate an increasing trend and negative values of $\mathrm{u}(\mathrm{t})$ indicate a decreasing trend.

\section{RESULTS}

Drought characteristics of Niğde Province are given in Tables 1-7 for 1-, 3-, 6-, 9-, 12-, 24- and 36month time scales. 6 drought events lasting 6-10 months occurred for the 1-month time scale and drought magnitude ranges between 4.02 and 11.14. 22 drought events lasting 6-17 months occurred for the 3-month time scale and drought magnitude ranges between 3.17 and 23.56. 22 drought events lasting 6-28 months occurred for the 6-month time scale and drought magnitude ranges between 1.72 and 47.35. 20 drought events lasting 6-41 months occurred for the 9-month time scale and drought magnitude ranges between 1.17 and 61.75. 17 drought events lasting 6-55 months occurred for the 12month time scale and drought magnitude ranges between 1.1 and 71.54. 14 drought events lasting 6-83 months occurred for the 24-month time scale and drought magnitude ranges between 0.91 and 109. 10 drought events lasting 6-73 months occurred for the 36-month time scale and drought magnitude ranges between 0.58 and 117.18 . 
Arslan / Anadolu Univ. J. of Sci. and Technology A - Appl. Sci. and Eng. 18 (5) - 2017

Table 1. Drought characteristics of Niğde Province for the 1-month time scale

\begin{tabular}{ccc}
\hline Number & Drought Duration & Drought Magnitude \\
\hline 1 & 8 & 5.19 \\
2 & 6 & 5.61 \\
3 & 9 & 7.25 \\
4 & 10 & 11.14 \\
5 & 6 & 4.02 \\
6 & 8 & 6.67 \\
\hline
\end{tabular}

Table 2. Drought characteristics of Niğde Province for the 3-month time scale

\begin{tabular}{ccc}
\hline Number & Drought Duration & Drought Magnitude \\
\hline 1 & 6 & 3.84 \\
2 & 10 & 9.02 \\
3 & 11 & 8.50 \\
4 & 12 & 13.00 \\
5 & 6 & 6.32 \\
6 & 8 & 8.41 \\
7 & 6 & 11.28 \\
8 & 6 & 4.42 \\
9 & 9 & 12.19 \\
10 & 17 & 23.56 \\
11 & 8 & 5.23 \\
12 & 7 & 4.02 \\
13 & 6 & 3.17 \\
14 & 9 & 9.74 \\
15 & 10 & 18.49 \\
16 & 13 & 9.90 \\
17 & 6 & 5.96 \\
18 & 7 & 9.19 \\
19 & 7 & 4.99 \\
20 & 6 & 3.43 \\
21 & 7 & 7.96 \\
22 & 6 & 5.20 \\
\hline
\end{tabular}

Table 3. Drought characteristics of Niğde Province for the 6-month time scale

\begin{tabular}{ccc}
\hline Number & Drought Duration & Drought Magnitude \\
\hline 1 & 6 & 3.36 \\
2 & 13 & 11.37 \\
3 & 8 & 3.79 \\
4 & 26 & 33.93 \\
5 & 7 & 5.13 \\
6 & 7 & 8.00 \\
7 & 16 & 20.08 \\
8 & 10 & 6.51 \\
9 & 28 & 47.35 \\
10 & 7 & 6.54 \\
11 & 8 & 3.83 \\
12 & 6 & 1.72 \\
13 & 7 & 2.05 \\
14 & 12 & 12.53 \\
15 & 9 & 19.46 \\
16 & 22 & 20.27 \\
17 & 6 & 3.00 \\
18 & 8 & 11.56 \\
19 & 12 & 8.68 \\
20 & 15 & 9.85 \\
21 & 10 & 8.55 \\
22 & 9 & 7.41 \\
\hline
\end{tabular}


Arslan / Anadolu Univ. J. of Sci. and Technology A - Appl. Sci. and Eng. 18 (5) - 2017

Table 4. Drought characteristics of Niğde Province for the 9-month time scale

\begin{tabular}{ccc}
\hline Number & Drought Duration & Drought Magnitude \\
\hline 1 & 26 & 17.14 \\
2 & 6 & 2.73 \\
3 & 25 & 39.17 \\
4 & 8 & 6.65 \\
5 & 18 & 23.12 \\
6 & 41 & 61.75 \\
7 & 7 & 4.60 \\
8 & 6 & 1.34 \\
9 & 8 & 3.80 \\
10 & 11 & 11.12 \\
11 & 12 & 19.79 \\
12 & 10 & 3.80 \\
13 & 6 & 1.17 \\
14 & 25 & 24.45 \\
15 & 13 & 5.35 \\
16 & 12 & 12.40 \\
17 & 16 & 10.62 \\
18 & 18 & 12.59 \\
19 & 10 & 8.88 \\
20 & 9 & 8.23 \\
\hline
\end{tabular}

Table 5. Drought characteristics of Niğde Province for the 12-month time scale

\begin{tabular}{ccc}
\hline Number & Drought Duration & Drought Magnitude \\
\hline 1 & 6 & 3.37 \\
2 & 27 & 18.89 \\
3 & 6 & 2.89 \\
4 & 25 & 40.42 \\
5 & 8 & 4.51 \\
6 & 16 & 23.68 \\
7 & 55 & 71.54 \\
8 & 17 & 10.86 \\
9 & 17 & 20.84 \\
10 & 6 & 3.48 \\
11 & 24 & 25.3 \\
12 & 7 & 1.10 \\
13 & 6 & 3.99 \\
14 & 12 & 11.65 \\
15 & 33 & 32.94 \\
16 & 12 & 7.85 \\
17 & 9 & 6.96 \\
\hline
\end{tabular}

Table 6. Drought characteristics of Niğde Province for the 24-month time scale

\begin{tabular}{ccc}
\hline Number & Drought Duration & Drought Magnitude \\
\hline 1 & 43 & 27.16 \\
2 & 13 & 5.06 \\
3 & 39 & 38.65 \\
4 & 83 & 109.00 \\
5 & 11 & 3.62 \\
6 & 25 & 12.98 \\
7 & 28 & 19.42 \\
8 & 31 & 24.95 \\
9 & 6 & 0.92 \\
10 & 9 & 5.23 \\
11 & 8 & 3.93 \\
12 & 41 & 34.84 \\
13 & 12 & 2.79 \\
14 & 7 & 3.33 \\
\hline
\end{tabular}


Arslan / Anadolu Univ. J. of Sci. and Technology A - Appl. Sci. and Eng. 18 (5) - 2017

Table 7. Drought characteristics of Niğde Province for the 36-month time scale

\begin{tabular}{ccc}
\hline Number & Drought Duration & Drought Magnitude \\
\hline 1 & 48 & 33.35 \\
2 & 6 & 0.58 \\
3 & 47 & 39.46 \\
4 & 73 & 117.18 \\
5 & 8 & 2.19 \\
6 & 37 & 15.5 \\
7 & 20 & 14.71 \\
8 & 50 & 26.29 \\
9 & 8 & 1.83 \\
10 & 45 & 36.49 \\
\hline
\end{tabular}

MKRC trend analysis results are given in Table 8 . As can be seen from the table, study period between 1950 and 2015 revealed statistically significant increasing trends at the $95 \%$ confidence level for all time scales except a 1-month time scale. Graphics which are drawn to identify the beginning of a trend are given in Figure 2-8. The beginning of latest trend is 2008 for 1 and 36-month time scales, 2007 for 3-month time scale and 2014 for 6, 9, 12 and 24-month time scales.

Table 8. MKRC trend analysis results of Niğde Province for different time scales

\begin{tabular}{ccc}
\hline Time scale & $\mathbf{u}(\mathbf{t})$ & Trend Status (at the 95\% confidence level) \\
\hline 1 & 0.78 & Increasing Trend \\
3 & 2.69 & Statistically Significant Increasing Trend \\
6 & 3.29 & Statistically Significant Increasing Trend \\
9 & 3.09 & Statistically Significant Increasing Trend \\
12 & 3.20 & Statistically Significant Increasing Trend \\
24 & 4.27 & Statistically Significant Increasing Trend \\
36 & 5.34 & Statistically Significant Increasing Trend \\
\hline
\end{tabular}

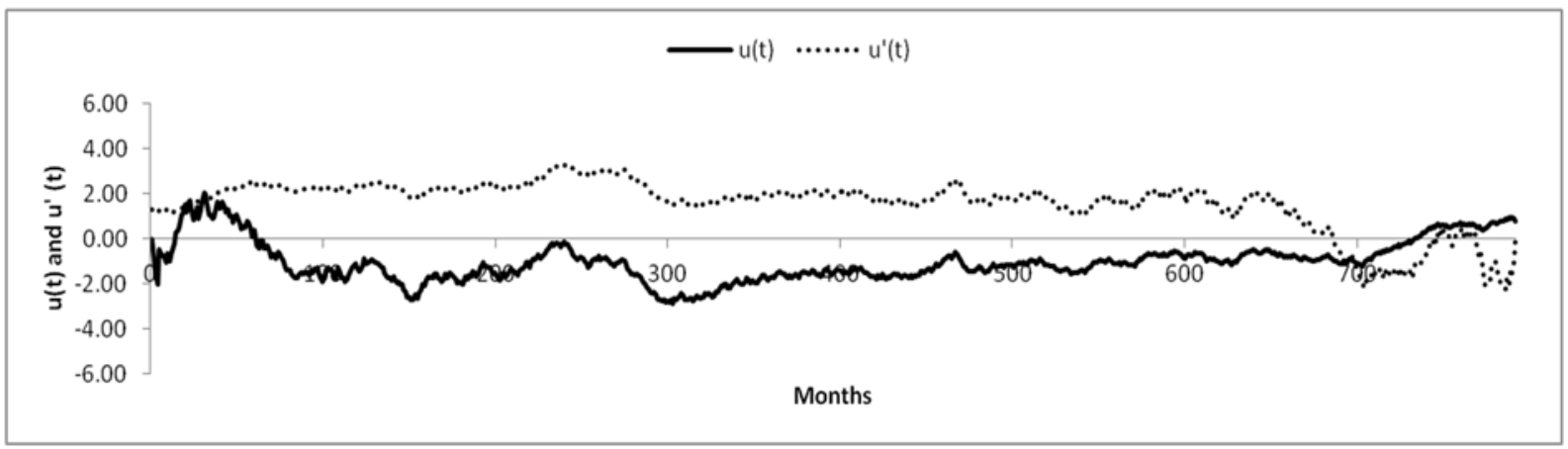

Figure 2. $u(t)$ and $u^{\prime}(t)$ values of Niğde province in terms of SPI 1

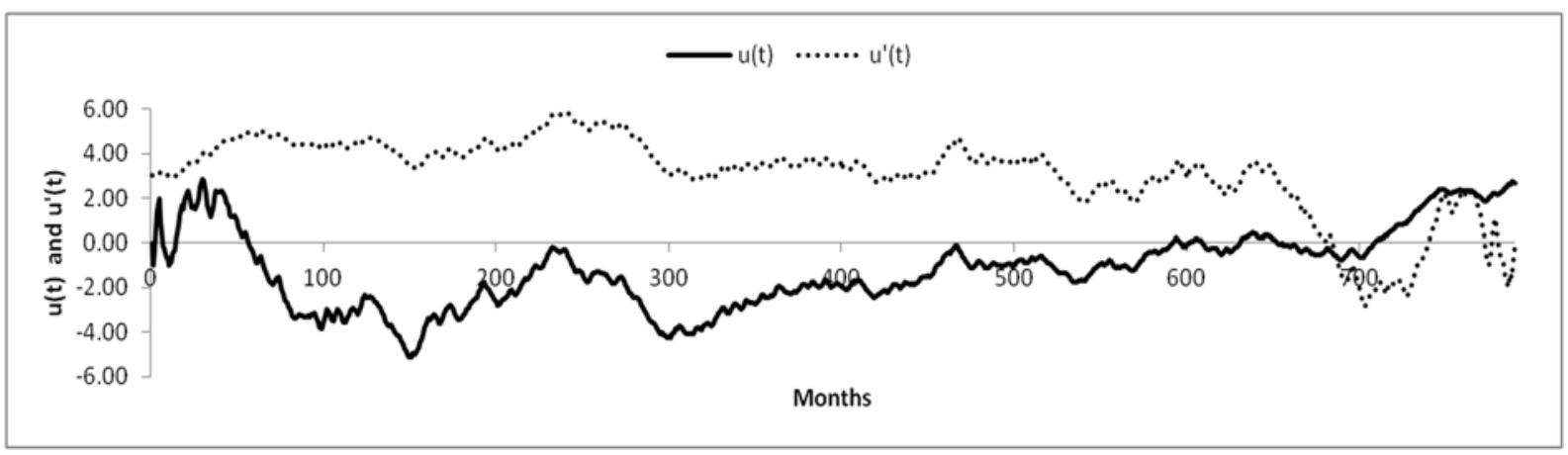

Figure 3. $u(t)$ and $u^{\prime}(t)$ values of Niğde province in terms of SPI 3 
Arslan / Anadolu Univ. J. of Sci. and Technology A - Appl. Sci. and Eng. 18 (5) - 2017

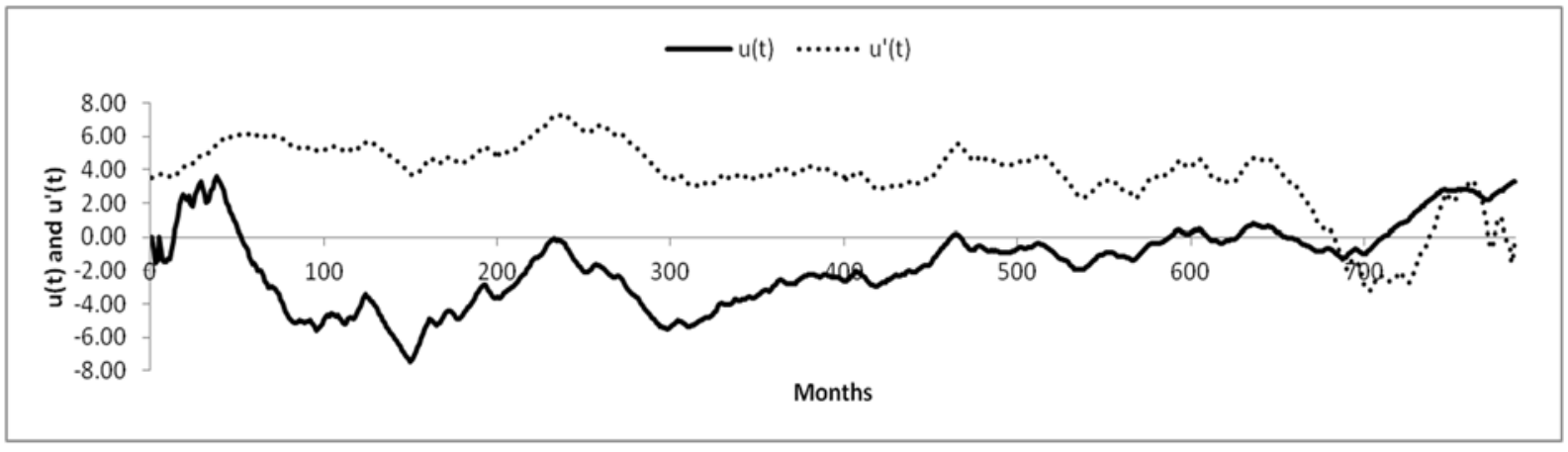

Figure 4. $u(t)$ and $u^{\prime}(t)$ values of Niğde province in terms of SPI 6

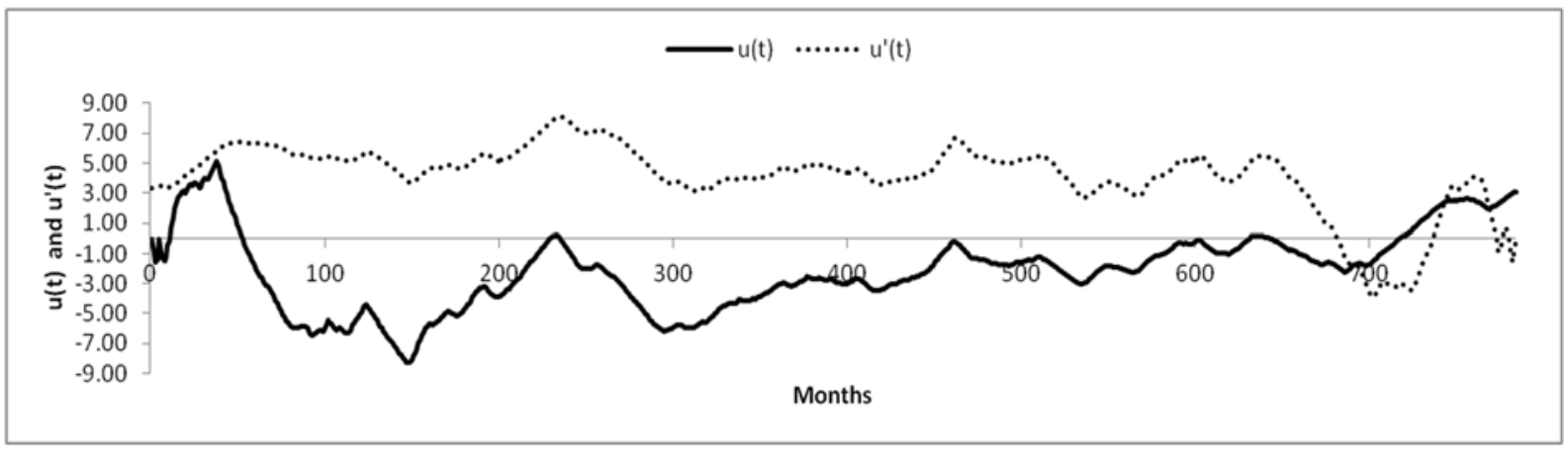

Figure 5. $u(t)$ and $u^{\prime}(t)$ values of Niğde province in terms of SPI 9

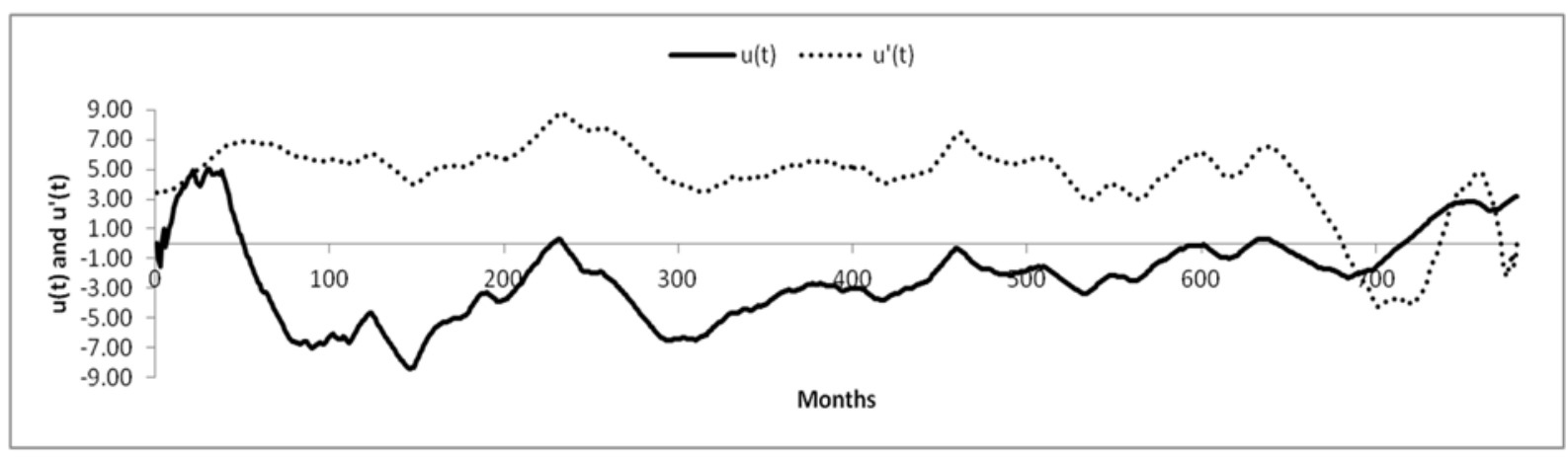

Figure 6. $u(t)$ and $u^{\prime}(t)$ values of Niğde province in terms of SPI 12

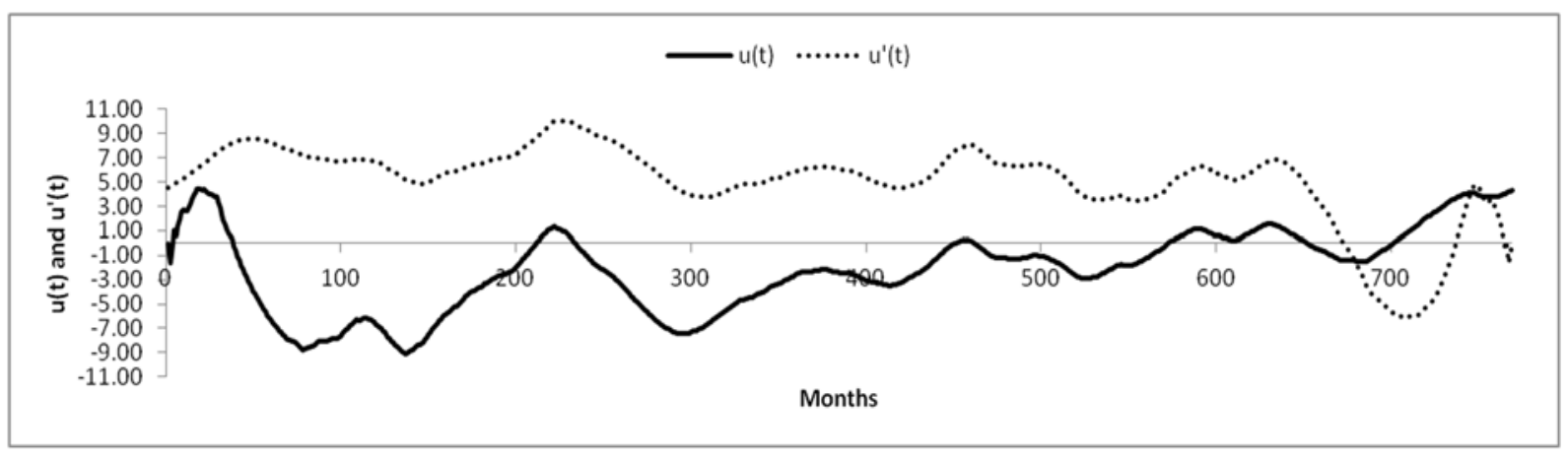

Figure 7. $u(t)$ and $u^{\prime}(t)$ values of Niğde province in terms of SPI 24 


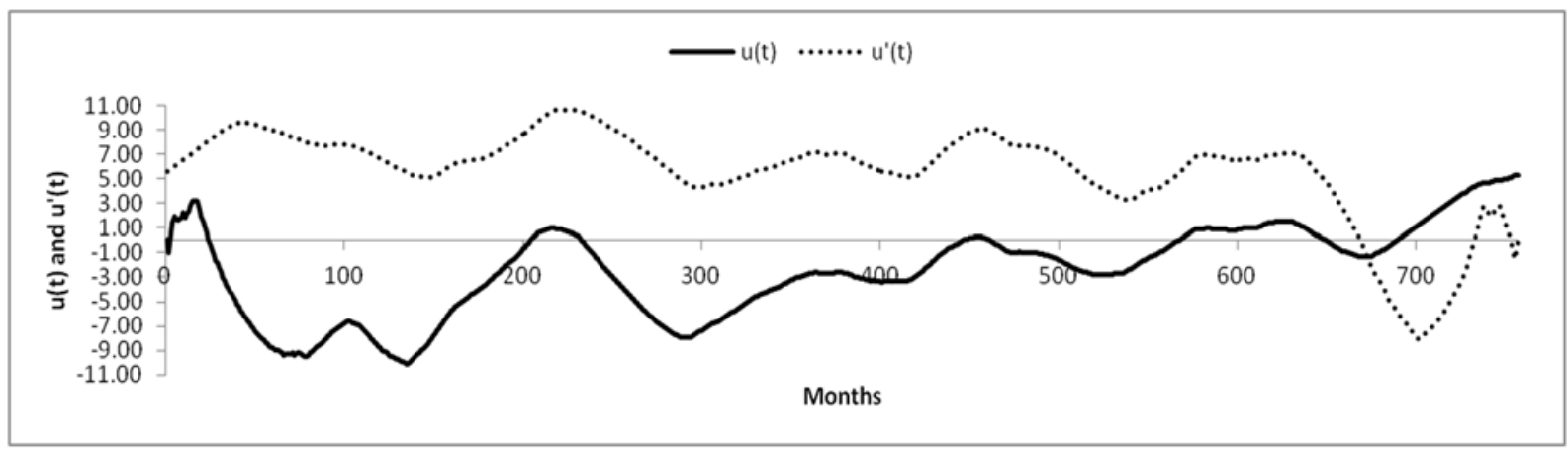

Figure 8. $u(t)$ and $u^{\prime}(t)$ values of Niğde province in terms of SPI 36

\section{CONCLUSION}

Number of droughts and maximum drought magnitudes for Niğde province for different time scales are given in Table 9. According to the table, 110 droughts lasting six months and more occurred between 1950 and 2015. It was determined that drought magnitude increases from 1-month time scale to 36-month timescale.

Table 9. MKRC trend analysis results of Niğde Province for different time scales

\begin{tabular}{ccc}
\hline Time scale & Number of droughts & Maximum drought magnitude \\
\hline 1 & 6 & 11.14 \\
3 & 22 & 23.56 \\
6 & 22 & 47.35 \\
9 & 20 & 61.75 \\
12 & 17 & 71.54 \\
24 & 14 & 109.00 \\
36 & 10 & 117.18 \\
Total & 110 & 441.52 \\
\hline
\end{tabular}

According to trend analysis, statistically significant increasing trends have been observed at the $95 \%$ confidence level for all time scales except 1-month time scale. Moreover, number and magnitude of droughts have been decreased in recent years when the drought characteristics of Niğde province given from Table 1 to Table 8 are examined. This means that SPI values have shown a tendency towards wetness in Niğde province. In other words, it shows that there has been an increasing trend in precipitation values. Precipitation values of Niğde province between 1950 and 2015 are given in Figure 9 and trend line is drawn for precipitation data. As can be from Figure 9, an increasing trend is observed for precipitation values. This increasing trend supports the results obtained from this study. Due to increasing trends in SPI values, a decrease in irrigation water is expected. Therefore, amounts of irrigation water should be recalculated and management of dams should be revised according to new irrigation water values. Thus, new amounts of irrigation water can save from irrigation water for Niğde province. 


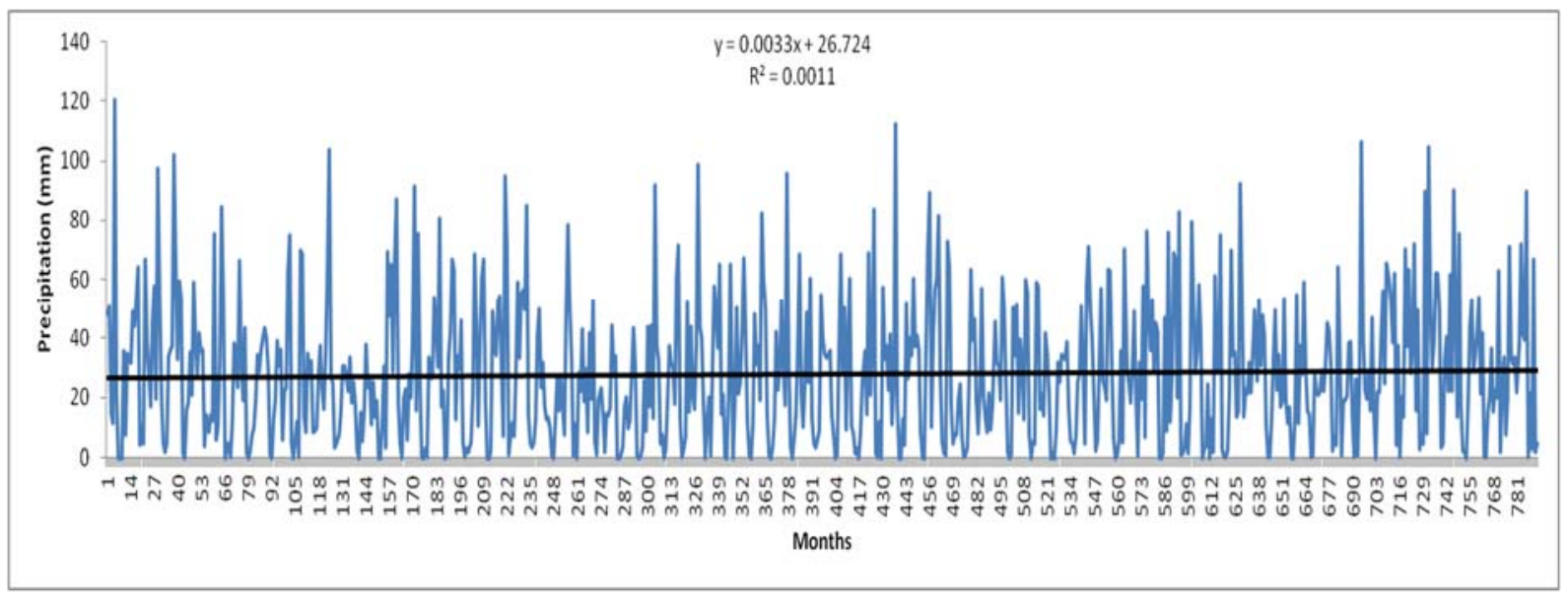

Figure 9. Precipitation values of Niğde province

\section{REFERENCES}

[1] Bryant EA. Natural Hazards. Cambridge: Cambridge University Press, 1993.

[2] Chen ST, Kuo CC, Yu PS. Historical trends and variability of meteorological droughts in Taiwan. Hydrolog Sci J 2009; 54: 430-441.

[3] Blain GC. Monthly values of the standardized precipitation index in the State of São Paulo, Brazil: trends and spectral features under the normality assumption. Agrometeorology 2012; 71: 122-131.

[4] Ganguli P, Reddy MJ. Evaluation of trends and multivariate frequency analysis of droughts in three meteorological subdivisions of western India. Int J Climatol 2014; 34: 911-928.

[5] Zhang Y, Cai W, Chen Q, Yao Y, Liu K. Analysis of Changes in Precipitation and Drought in Aksu River Basin, Northwest China. Advances in Meteorology 2015; 2015: 1-15.

[6] Achugbu IF, Anugwo SC. Drought trend analysis in Kano using Standardized Precipitation Index. Journal of Engineering and Technology 2016; 1: 105-110.

[7] Ionita M, Scholz P, Chelcea S. Assessment of droughts in Romania using the Standardized Precipitation Index. Nat Hazards 2016; 81: 1483-1498.

[8] Osuch M, Romanowicz RJ, Lawrence D, Wong WK. Trends in projections of standardized precipitation indices in a future climate in Poland. Hydrol Earth Syst Sci 2016; 20: 1947-1969.

[9] Zarei AR, Eslamian S. Trend assessment of precipitation and drought index (SPI) using parametric and nonparametric trend analysis methods (case study: arid regions of southern Iran). International Journal of Hydrology Science and Technology 2017; 7: 12-38.

[10] Sen B, Topçu S, Türkeş M, Sen B, Warner JF. Projecting climate change, drought conditions and crop productivity in Turkey. Climate Res 2012; 52: 175-191.

[11] Satılmıs, MM, Dagasan, M, Gürcü M, Kunt M, Gürbüzler D, Erkal İF, Hacıhasanoglu S, Ozer E. State of the Environment Report for Republic of Turkey. Ankara, Turkey: Sar Printing Press, 2016. 
Arslan / Anadolu Univ. J. of Sci. and Technology A - Appl. Sci. and Eng. 18 (5) - 2017

[12] McKee TB, Doeskenb NJ, Kleist J. The relationship of drought frequency and duration to time scales. In: 8th Conference on Applied Climatology; 17-22 January 1993; Anaheim, California, USA: pp. 179-184.

[13] Yıldırım U, Gazibey Y, Güngör A. Wind Energy Potential of Niğde Province. Niğde University Journal of Engineering Sciences 2012; 2: 37-47.

[14] Sneyers R. On the statistical analysis of series of observations. WMO 1990; 143: 192. 